\title{
O RELEVO DE ÁGUA VIVA: CLARICE LISPECTOR E A ESCRITA DA PAISAGEM
}

Tatiane Costa Souza*

RESUMO: Este trabalho pretende averiguar o movimento "impessoal" que se destaca no relevo da escrita de Clarice Lispector. Para isso, será feita uma leitura, privilegiando o livro Água viva e algumas passagens de $A$ paixão segundo G.H e Um sopro de vida, que possibilite verificar como a composição do texto clariceano se lança rumo ao "vivo", ao não humano, ao aberto da paisagem.

PALAVRAS CHAVE: Clarice Lispector; Água viva; impessoal; relevo; paisagem.
* tattianecs@gmail.com

Doutoranda em Teoria da Literatura e Literatura Comparada pela Letras da UFMG.

RESUMEN: Este trabajo propone investigar el movimiento "impersonal" que se destaca en el relieve de la escritura de Clarice Lispector. Para ello se hará una lectura, dando la prioridad al libro Agua viva y algunos pasajes de La pasión según G.H. y Un soplo de vida, que posibilite verificar como la composición de texto clariceano se lanza en la dirección de lo "vivo", de lo no humano, de lo abierto del paisaje.

PALABRAS-CLAVE: Clarice Lispector; Agua viva; impersonal; relieve; paisaje. 
1. Cf. SEVERINO. As duas versões de Agua viva. In: Remate de Males, p. 117.

2. LISPECTOR. Água viva, p. 35

3. BRANCO. O sopro Clarice. In ; BRANDÃO. A mulher $\overline{\text { escrita, p. } 210 .}$
Quer ver comigo? Paisagem onde se passa essa música? ar, talos verdes, o mar estendido, silêncio de domingo de manhã. Um homem fino de um pé só tem um grande olho transparente no meio da testa. Um ente feminino se aproxima engatinhando, diz com voz que parece vir de outro espaç, voz que soa não como a primeira voz mas em ce de coutro espaco, voz que so não co [ ] Um novo pez mon em eco de uma voz prineira que não se ouviu. [...] Un novo personagen ove-se: $p$ siu psiu! E chama-se ninguém.

Clarice Lispecto

Água viva, de Clarice Lispector, foi publicado no ano de 1973. No entanto, esse livro passou por profundas alterações até que chegasse ao seu conteúdo final. A primeira versão extensa, que a princípio parecia ser definitiva, foi escrita por Clarice no ano de 1971. Essa versão, ainda um verso de um rascunho, intitulava-se Atrás do pensamento: monólogo com vida. Depois, passa a se chamar Objeto gritante. No entanto, nenhum dos dois títulos prevalece.

Ao seguir rumo à versão final do livro, a autora opera com um trabalho de corte e redução, pois, para chegar ao que conhecemos hoje como Agua viva, ela teria eliminado mais de cem páginas. ${ }^{1}$ A razão de Clarice cortar parte do que já havia sido escrito resultava de uma preocupação em eliminar os dados de caráter mais pessoal ou autobiográficos. $\mathrm{Na}$ versão final, esse corte aparece através da escrita de um movimento da "bio", ${ }^{2}$ de um vivo - "a vida em seu sentido mais visceral". ${ }^{3}$ Portanto, será essa escrita do vivo, ocasionada por uma passagem do pessoal ao impessoal, que averiguaremos no texto da autora em questão. Para isso, circunscreveremos dois movimentos que se destacam no relevo da escrita clariceana: "Ele”, "ela”, "ninguém”; "Eu”, "tu”, "it”.

PRIMEIRO MOVIMENTO: “ELE”, “ELA”, “NINGUÉM”

$\mathrm{Na}$ infinitude do espaço do livro Água viva, letras e mais letras se agrupam, disseminando sentidos diversos. As palavras pendem entre as acácias amarelas e formam um "intenso matagal". ${ }^{4}$ Nessa "densa selva de palavras", página a página linha a linha, letra a letra, fios incessantes de voz e silêncio, emaranhados entre ramos e raízes, cobrem o espaço a ser desbravado pela leitura. Em meio à ramificação desses fios de letras, encontram-se vestígios de vida, de morte, de voz, de olhar, de silêncio, de solidão.

Durante a leitura, passamos, de instante em instante pelos rastros das letras deixados nas páginas. Nesse movimento, é possível percebermos que o espaço do livro Água viva, povoado por palavras e sentidos diversos, abre-se em um horizonte aberto. Lá, as palavras espocam, escorrem, espraiam. Lá, lemos sobre telas brancas, superfícies crestadas, espelhos vazios, jardins com águas correndo, gritos de pássaros, plantas e plantas, luar canhestro, tensão mágica e silenciosa do sol. Lá há dimensões nas quais seres e coisas se misturam. 
Nesse cenário, composto por uma paisagem, pelo vivo, a narradora de Água viva anuncia que começa as primeiras páginas com o desejo pela pintura, mas segue tomada pelo gosto das palavras. A escrita corre, então, em um fluxo de letras aquosas e, na sequência das páginas, entramos em um mundo que abriga um "emaranhado de cipós, sílabas, madressilvas, cores e palavras". ${ }^{5}$ A dimensão desse mundo se expande por diversos espaços: grutas escuras e nimbadas de claridade; um jardim todo maduro de perfumes; fontes, lagoas e cachoeiras. Lá, há o mergulho na matéria pela palavra, o mergulho na escrita pela palavra, o mergulho na palavra pela palavra afluindo no aberto de um horizonte: Água viva.

Da leitura que se faz pela paisagem desse livro, e, aqui, podemos tomar a última como o próprio relevo do texto, encontramos, logo nas primeiras páginas de Água viva, uma frase na qual aparecem algumas palavras entre aspas, e/ou em relevo. Lá, lemos: "E se eu digo 'eu' é porque não ouso dizer 'tu', ou 'nós' ou 'uma pessoa', sou obrigada à humildade de me personalizar me apequenando mas sou o és-tu." $\mathrm{Se}$ recortarmos dessa frase aquilo que está entre aspas, eis o que resta: um eu, um tu, um nós, uma pessoa. Notamos que há breves tentativas de personalização na escrita de Água viva. Ao adentrarmos nas páginas desse livro, é possível percebermos alguns pronomes pessoais evocados entre aspas e, quem sabe, a tentativa de construção, que sempre fracassa de uma narrativa que conte uma história humana.
Diante da humildade de uma possível personalização, um "ele"/um "ela" aparecem, acolhidos, primeiramente, pelas dobras das aspas. ${ }^{7}$ Nesse contexto, aquela que narra os instantes das palavras diz que em breve estará "pronta para falar em 'ele' ou 'ela". ${ }^{8}$ Mas essa brevidade cada vez mais se distancia, pois esses pronomes, masculino/feminino, aparecem ligeiramente para logo se rarefazerem pelo espaço do livro, como podemos ver em algumas passagens.

Ao contar sobre filhotes de coruja e cavalos soltos, um "ele" surge fundido à paisagem do "vale dos altos Pireneus nevados":

O ele contou-me que morou durante algum tempo com parte de sua família que vivia em pequena aldeia em um vale dos altos Pirineus nevados. No inverno os lobos esfaimados desciam das montanhas até a aldeia a farejar presa. Todos os habitantes se trancavam atentos em casa a abrigar na sala ovelhas e cavalos e cães e cabras, o calor humano e calor animal - todos alertamente a ouvir o arranhar das garras dos lobos nas portas cerradas. A escutar. A escutar.

O ele desaparece. As páginas são, então, atravessadas pelo segredo das manhãs. A narradora conta sobre uma rosa, cujo gesto de sobrevivência, sustentado por dias a fio, lembrava os mistérios animais. Em seguida, um "ela" é mencionado em meio aos instintos abafados de bichos e gritos ancestrais: "Conheci um 'ela' que humanizava bicho conversando
7. Em alguns momentos, o ele/ ela aparecem entre aspas, em outros, sem as mesmas, mas, ainda assim, as aspas se tornam condutores da leitura.

8. LISPECTOR. Água viva, p. 38.

9. LISPECTOR. Água viva, p. 50.
EM TESE v. 21

N. 3 
10. LISPECTOR. Água viva, p. 49.

11. LISPECTOR. Água viva, p. 52.

12. LISPECTOR. Água viva, p. 92

13. LISPECTOR. Água viva, p. 37.

14. LISPECTOR. Água viva, p. 52

17. LISPECTOR. Água viva, p. 21 com ele e emprestando-lhe as próprias características. Não humanizo bicho porque é ofensa - há que respeitar-lhe a natureza - eu é que me animalizo." ${ }^{10}$ Adiante, novamente, um "ela" aparece para logo morrer: "Soube de um ela que morreu na cama mas aos gritos: estou me apagando! Até que houve o benefício do coma dentro do qual o ela se libertou do corpo e não teve nenhum medo de morrer."11

Lemos também sobre um ela/um ele que se apavoram diante da paisagem da natureza. Como a narradora conta:

Conheço um ela que se apavora com borboletas como se estas fossem sobrenaturais. E a parte divina das borboletas é mesmo de dar terror. E conheço um ele que se arrepia todo de horror diante de flores - acha que as flores são assombradamente delicadas como um suspiro de ninguém no escuro. ${ }^{12}$

Como é possível percebermos, a narradora, vez ou outra faz menção a um ele/um ela que se misturam aos fios da paisagem de Água viva - sejam eles plantas, bichos, "suspiros de ninguém no escuro". Afinal, ela ainda não está "pronta para falar em 'ele' ou 'ela', pois demonstra 'aquilo'. Aquilo é lei universal. Nascimento e morte”. ${ }^{13}$ Por enquanto, o que a "sustenta é o 'aquilo' que é um 'it”. ${ }^{14}$

Nesse sentido, observamos que, diante do apagamento de um ele/um ela, aos poucos, um tom anônimo ganha voz no livro. Um corpo de ninguém começa a se compor através da tessitura da escrita. Sobre isso, lemos: "Na hora de pintar ou escrever sou anônima. Meu profundo anonimato que nunca ninguém tocou." ${ }^{15}$ Ela inteira, à medida que rola no chão, vai se "acrescentando em folhas". Ela, "obra anônima de uma realidade anônima”, vai aquém e além de sua história humana. Ela, anônima, escreve:

Para me interpretar e formular-me preciso de novos sinais e articulações novas em formas que se localizem aquém e além de minha história humana. Transfiguro a realidade e então outra realidade sonhadora e sonâmbula, me cria. E eu inteira rolo e à medida que rolo no chão vou me acrescentando em folhas, eu, obra anônima de uma realidade anônima só justificável enquanto dura a minha vida. E depois? depois tudo o que vivi será de um pobre supérfluo. Mas por enquanto estou no meio do que grita e pulula. E é sutil como a realidade mais intangível. Por enquanto o tempo é quanto dura um pensamento. ${ }^{16}$

$\mathrm{Na}$ durabilidade de um pensamento, que se faz com gritos de aleluia, destacamos uma passagem na qual a narradora se lança para outro lado: "a transfiguração me aconteceu. Mas o outro lado, do qual escapei mal e mal, tornou-se sagrado [...]. Ninguém saberá de nada: o que sei é tão volátil e quase inexistente que fica entre mim e eu" ${ }^{17}$ Há, pois, um lado 
18. LISPECTOR. Um sopro de vida, p. 79 .

19. LISPECTOR. Água viva, p. 82

20. LISPECTOR. Água viva, p. 35 sagrado, secreto, um lugar que, por sua quase inexistência, ninguém sabe contar.

Nesse outro lado, o tom anônimo se intensifica e um terceiro que nomearemos, por enquanto, de "um ninguém da escrita", escreve-se. Sobre isso, lemos em Um sopro de vida: "O que escrevo agora não é para ninguém: é diretamente para o próprio escrever, esse escrever consome o escrever." ${ }^{18} \mathrm{Já}$ em Água viva, encontramos outro rastro de ninguém: "Estive só. Só de ti. Escrevo para ninguém e está-se fazendo um improviso que não existe. Descolei-me de mim." ${ }^{19}$

No que se refere ao ninguém, ao processo de descolagem, é possível pensar na composição de Água viva, cujo método envolveu o corte de traços pessoais de Clarice Lispector. Nesse movimento, notamos o desaparecimento de uma pessoalidade e mais vestígios de ninguém deixados nesse livro: "Comi minha própria placenta para não precisar comer durante quatro dias. Para ter leite para te dar. O leite é um 'isto'. E ninguém é eu. Ninguém é você. Esta é a solidão." ${ }^{20}$ Disso, desdobra-se um ninguém que escreve para ninguém; um gesto solitário que atravessa os fios do texto; um tom anônimo da escrita; um "aquilo"; um "isto" - "uma melodia sem palavras":

Ontem eu estava tomando café e ouvi a empregada na área de serviço a pendurar roupa na corda e a cantar uma melodia sem palavras. Espécie de cantilena extremamente plangente.
Perguntei-lhe de quem era a canção e ela respondeu: é bobagem minha mesmo, não é de ninguém. Sim, o que te escrevo não é de ninguém. ${ }^{21}$

O que ela escreve não é de ninguém. Se "essa liberdade de ninguém é muito perigosa. É como o infinito que tem cor de ar", ${ }^{22}$ se "o ar é it", ${ }^{23}$ essa liberdade caminha para um impessoal, um neutro, uma terceira dimensão. Mas se não há, nem ele, nem ela, como localizar esse terceiro que se escreve?

Para avançarmos nesse ponto, primeiramente, recorremos às elaborações de Jacques Lacan sobre o feminino. Cabe lembrar que foi na travessia dos conceitos psicanalíticos que Lacan formulou uma nova forma de pensar $A$ mulher. ${ }^{24} \mathrm{Se}$ para Freud o feminino seria qualificado como um "continente negro", ${ }^{25}$ Lacan segue por outro caminho, ao trabalhar a lógica do "não-todo" e do gozo como algo ininteligível. N’O seminário, livro 20: mais, ainda, Lacan, ao diferenciar a posição feminina da masculina, estabelecerá que parte do gozo feminino é ligado à lógica fálica, mas que existe outra parte do gozo que a mulher não sabe dizer. Ou seja, o gozo d'a mulher está para além do falo, pois a posição feminina é ser ela não-toda submetida ao falo. Nesse sentido, não há uma palavra que defina a mulher, pois o significante falta.

Portanto, o feminino será o que mais resistirá em se inscrever, seja no corpo anatômico (pois a mulher não tem o
21. LISPECTOR. Agua viva, p. 83.

22. LISPECTOR. Água viva, p. 83. 23. LISPECTOR. Água viva, p. 63.

24. Cf. LACAN. O seminário livro 20: mais, ainda, p. 100.

25. FREUD. A questão da análise leiga: conversações com uma estudo autobiográfico inibições sintomas e ansiedade; a questão da análise leiga; outros trabalhos. (1925-1926), p. 205. 
26. POMMIER. O Aberto, até onde as palavras podem nos transportar: In: A exceção feminina: os impasses do gozo, p. 102

27. LACAN. $O$ aturdito. In: Outros escritos, p. 467.

28. LISPECTOR. Água viva, p. 13 falo), seja no campo simbólico da linguagem. Através dessas elaborações, Lacan propõe pensar a mulher em outra lógica: "a mais" do gozo, "além", que nada significa à medida que não se inscreve no corpo, ou seja, um gozo ininteligível, que somente goza sem palavra alguma que o traduza. Sobre isso, ressoam estas palavras de Gerard Pommier: "O poeta um místico, uma mulher mostram [...] nessa escolha do 'sem abrigo', de um fundamento sem fundo, a região essencia onde o falar apresenta sua união com o gozo de um Todo que se apoia no nada." ${ }^{26}$ Do Todo ao nada, do "sem abrigo" à solidão, lemos, em Lacan: "Mas é também nisso que se aprende o que há por aprender, isto é, que mesmo que se satisfaça a exigência do amor, o gozo que se tem da mulher a divide, fazendo-a parceira de sua própria solidão, enquanto a união permanece na soleira”. ${ }^{27}$

Em Água viva, a união de um ele/um ela também fica na soleira e há uma recusa das tentativas de classificação: "Inútil querer me classificar: eu simplesmente escapulo não deixando, gênero não me pega mais." ${ }^{28}$ Nesse sentido, é possível pensarmos, a partir das construções lacanianas, em uma aproximação desse feminino, cuja parceria se dá com a própria solidão, com a escrita de Clarice, mais especificamente de Água viva, cujo caminho aponta para um ninguém.

Mas se o texto, cujo abandono de um ele/um ela, cujo apoo se dá no nada, aproxima-se desse feminino, parece-nos que se trata, também, de outra dimensão do feminino. Para avançarmos nesse ponto, citamos a seguinte construção: "O risco - estou arriscando descobrir terra nova. Onde jamais passos humanos houve." ${ }^{29}$ No risco, em mais um passo, ao longo da travessia da leitura desse livro, rumamos ao inumano. Sobre isso, lemos: "Minha noite vasta passa-se no primário de uma latência. A mão pousa na terra e escuta quente um coração a pulsar. Vejo a grande lesma branca com seios de mulher: é ente humano? Queimo-a em fogueira inquisitorial." ${ }^{30}$

Posto isso, lançamos a seguinte questão: se há um feminino, cuja parceria se dá com a própria solidão, se há uma escrita que caminha na direção de um ninguém, de "onde jamais passos humanos houve", esse feminino é "ente humano?" Para iluminar essa questão, citamos uma passagem de Freud, extraída da conferência "feminilidade":

Isto é tudo o que tinha a dizer-lhes a respeito da feminilidade. Certamente está incompleto e fragmentário, e nem sempre parece agradável. Mas não se esqueçam de que estive apenas descrevendo as mulheres na medida em que sua natureza é determinada por sua função sexual. É verdade que essa influência se estende muito longe; não desprezamos, todavia, o fato de que uma mulher possa ser uma criatura humana também em outros aspectos. Se desejarem saber mais a respeito da
29. LISPECTOR Água viva, p. 44

30. LISPECTOR Água viva, p. 38.
EM TESE
BELO HORIZONTE
SET.-DEz. 2015 
31. FREUD. Feminilidade. In: Novas conferências introdutórias sobre psicanálise e outros trabalhos. (1932-1936), p. 134.

32. LISPECTOR. Água viva, p. 54

33. LISPECTOR. Água viva, p. 28-29. feminilidade, indaguem da própria experiência de vida dos senhores, ou consultem os poetas, ou aguardem até que a ciência possa dar-lhes informações mais profundas e mais coerentes. ${ }^{31}$

Nessa elaboração, Freud deixa em aberto o fato de que a mulher, ou, mais ainda, o feminino, "possa ser uma criatura humana”. Há a possibilidade de um humano, mas, parece-nos, pode haver também, outra possibilidade, estranha e arriscada, do feminino estar próximo do não humano. Sobre a afluência dessa segunda possibilidade, recortamos duas passagens de Água viva.

Primeiramente, na lucidez da escrita, ela conta: "Estou terrivelmente lúcida e parece que alcanço um plano mais alto de humanidade. Ou da desumanidade - o it." ${ }^{\prime 2}$ Por essa via, do não humano, também lemos:

Mas vou me seguindo. Elástica. É um tal mistério essa floresta onde sobrevivo para ser. Mas agora acho que vai mesmo. Isto é: vou entrar. Quero dizer: no mistério. Eu mesma misteriosa e dentro do âmago em que me movo nadando, protozoário. Um dia eu disse infantilmente: eu posso tudo. Era a antevisão de poder um dia me largar e cair num abandono de qualquer lei. Elástica. A profunda alegria: o êxtase secreto. Sei como inventar um pensamento. Sinto o alvoroço da novidade. Mas bem sei que o que escrevo é apenas um tom. Nesse âmago tenho a estranha impressão de que não pertenço ao gênero humano. ${ }^{33}$
Elástica, prolongando-se pelas dobras da palavra, ela adentra uma floresta onde sobrevive para ser. Elástica, ela entra no mistério, em profunda alegria de um "êxtase secreto". E eis que, nesse caminho, na composição de um pensamento, de um tom da escrita, emerge uma estranha impressão de não pertencimento ao gênero humano - uma "solidão de não pertencer". ${ }^{34}$

\section{SEGUNDO MOVIMENTO: “EU”, “TU”, “IT"}

É possível percebermos que há vestígios do impessoal deixados, não somente em Água viva, mas ao longo da obra clariceana. Essas marcas do neutro, de uma paisagem que se abre, parecem ser tentativas de ultrapassar os limites do humano, na travessia que a própria escrita "exigiu" que Clarice Lispector fizesse. Sobre isso, Evando Nascimento, no livro Clarice Lispector: uma literatura pensante, observa:

A literatura de Clarice tem ajudado a questionar os limites do humano, na medida mesma em que traz para seu espaço formas concorrentes em relação à tradição, tais como animais e objetos, texturas, paisagens, cores, trechos musicais, ruídos e silêncios. Uma partitura de matérias e assuntos inusitados para a composição clássica. Textos como o "Ovo e a galinha", ou "A quinta história", Onde estivestes de noite, "O relatório da coisa", A paixão segundo G.H., Um sopro de vida, além do excepcional Água viva, ficcionalizam certo não humano não como aquilo
34. LISPECTOR. A descoberta do mundo, p. 111. 
35. NASCIMENTO. Clarice Lispector: Uma literatura pensante, p. 27.

36. Cf. BLANCHOT. O livro por vir, p. 292-293.

37. SANT'ANNA. O ritual epifânico do texto. In: NUNES (coord.). A paixão segundo G.H. (Edição crítica), p. 255.

38. NUNES. Clarice Lispector ou o naufrágio da introspecção. In Remate de Males, p. 67-68. que ameaça o homem, mas, ao contrário, contribui para o ultrapasse das barreiras impostas pela civilização dita ocidental no avançado estágio de seu desenvolvimento tecnológico. ${ }^{35}$

$\mathrm{Na}$ formação dessa escrita composta por animais, texturas, paisagens, podemos observar uma tentativa de Clarice em construir, desconstruindo, muitas vezes, um pensamen to que, ao ultrapassar os limites da linguagem e, mais ainda do humano, rume para o desaparecimento dos traços autobiográficos. Nesse sentido, no movimento que a escrita faz para alcançar essa experiência de apagamento, assistimos a um caminhar da própria obra rumo ao espaço deserto e neutro do impessoal. ${ }^{36}$

Parece-nos ser na direção da impessoalidade que a escrita de A paixão segundo G.H. também caminha. Nesse livro, anterior a Água viva, escrito em meados de 1963, a personagem G.H. vai além das fronteiras do humano, principalmente, quando coloca na boca a massa branca da barata. Do branco da matéria restam marcas do impessoal, que se propagam na continuidade da obra clariceana.

Há algumas leituras de G.H. que apontarão que "a mulher (G.H.) e a barata têm uma relação de complementariedade binária". ${ }^{37}$ No entanto, pensamos que entre a mulher e a barata não há uma relação binária, pois há a entrada de um terceiro elemento branco: "a matéria neutra, a vida crua" ${ }^{38}$
A fim de tentar localizar a entrada desse terceiro, coberto de impessoalidade, faremos uma digressão pelo livro $A$ paixão segundo G.H.

A história - que converge com Água viva, pois também não conta história alguma - do encontro de G.H. com o impessoal acontece quando a personagem entra no quarto da empregada, abandonado, como um quarto de ninguém. Lá há um som inaudível - "como o de uma agulha rodando no disco quando a faixa de música já acabou. Um chiado neutro de coisa, era o que fazia a matéria de seu silêncio". ${ }^{39}$ Neste cenário, silencioso, neutro, impessoal, G.H. encontra uma barata no armário e fecha a porta sobre seu corpo. Desse ato, começa a brotar da barata uma matéria branca - matéria que G.H., depois de passagens de silêncio no quarto, coloca em sua própria boca.

Antes do encontro com o neutro, havia a persona, a máscara: "Para escapar do neutro, eu há muito havia abandonado o ser pela persona, pela máscara humana. Ao me ter humanizado, eu me havia livrado do deserto." ${ }^{40}$ Depois da matéria branca, havia a falta de gosto do impessoal: "Eu sabia que o neutro da barata tem a mesma falta de gosto de sua matéria branca." ${ }^{41} \mathrm{E}$, por fim, havia o medo: "O medo que eu sempre tive do silêncio com que a vida se faz. Medo do neutro. O neutro era a minha raiz mais profunda e mais viva - eu olhei a barata e sabia." ${ }^{42}$
39. LISPECTOR. A paixão segundo G.H., p. 42.

40. LISPECTOR A paixão segundo G.H., p. 91-92.

41. LISPECTOR. A paixão segundo G.H., p. 85.

42. LISPECTOR. A paixão segundo G.H., p. 91. 
43. LISPECTOR. A paixão segundo G.H., p. 101.

44. LISPECTOR. A paixão segundo G.H., p. 173.

45. LISPECTOR. A paixão segundo G.H., p. 174.
Para entrar no neutro, a personagem abandona sua organização humana. Nessa travessia rumo ao impessoal, aquilo que é "inexplicável e vivo", ${ }^{43}$ G.H., assim como Clarice Lispector (C.L.), sabia que era preciso operar com o abandono; sabia que era preciso renunciar a algo; sabia que era preciso desconstruir. Sobre isso, lemos: "Mas agora, através de meu mais difícil espanto - estou enfim caminhando em direção ao caminho inverso. Caminho em direção à destruição do que construí, caminho para a despersonalização." ${ }^{44}$

No caminho da desconstrução, segue a obra clariceana, ao recompor, com as ruínas dos traços daquela que escreve, com aquilo que resta, a escrita de um pensamento que se sustenta pelos abismos da palavra. Parece-nos que Clarice sabia que a experiência de despersonalização não se daria sem desistências e perdas, pois, para prosseguir nesse "caminho inverso", é preciso, pouco a pouco, tirar algo de si "com um esforço tão atento que não se sente a dor, tirar de si, como quem se livra da própria pele". ${ }^{45}$ Parece-nos, também, que tenha sido em meio aos gestos de renúncia e corte, ao buscar o apagamento de si mesma, que Clarice tenha se lançado, em sua obra, na escrita de Água viva, em direção a um impessoal.

Desse modo, daquilo que é cortado, recortado, para que a água, em sua vivacidade, possa escorrer sulcando um traço pelo livro, resta o impessoal. Para nos orientarmos nessa via da leitura, seguimos, novamente, pelo caminho das dobras das aspas em Água viva. Desta vez, sem o "eu", o "ele", o "ela" ou "uma pessoa", resta, abrigado nas dobras das aspas, o elemento puro, o " $i t$ ". Sobre isso, a narradora, que é "it" e nasce das escuridões, escreve:

Nasci por Ordem. Estou completamente tranquila. Respiro por Ordem. Não tenho estilo de vida: atingi o impessoal, o que é tão difícil. Daqui a pouco a Ordem vai me mandar ultrapassar o máximo. Ultrapassar o máximo é viver o elemento puro. Tem pessoas que não aguentam: vomitam. Mas eu estou habituada ao sangue. ${ }^{46}$

$\mathrm{Na}$ ultrapassagem dos limites da linguagem, na entrada pelo mistério do impessoal, sem o pessoal que às vezes a encharca, ela se aproxima daquilo que é seco, duro e, outras vezes, mole como o pensamento de uma ostra - daquilo que é vivo:

Sou-me. Mas há também o mistério do impessoal que é o "it": eu tenho o impessoal dentro de mim e não é corrupto e apodrecível pelo pessoal que às vezes me encharca: mas seco-me ao sol e sou um impessoal de caroço seco e germinativo. Meu pessoal é húmus na terra e vive do apodrecimento. Meu "it" é duro como uma pedra-seixo. A transcendência em mim é o "it" vivo e mole e tem o pensamento que uma ostra tem. Será 
47. LISPECTOR. Água viva, p. 30.

48. LISPECTOR. Água viva, p. 30-31. que a ostra quando arrancada de sua raiz sente ansiedade? Fica inquieta na sua vida sem olhos. Eu costumava pingar limão em cima da ostra viva e via com horror e fascínio ela contorcer-se toda. E eu estava comendo o it vivo. O it vivo é o Deus. ${ }^{47}$

Se o vivo, o "it", é Deus, o Deus é também o mundo. Notamos a aproximação do impessoal com aquilo que existe no espaço do mundo, que é, também, como uma prece, uma meditação sobre o nada. Das palavras que se compõem e existem em apagamento, lemos o seguinte: "Vou parar um pouco porque sei que o Deus é o mundo. É o que existe. [...] A prece profunda é uma meditação sobre o nada. É o contato seco e elétrico consigo, um consigo impessoal." ${ }^{48} \mathrm{O}$ " $i t$ " vivo é também plasma, leite, ostra, placenta. Há, assim, das ruínas dos traços que restam, sem ele nem ela, aquilo que vivo vibra, aquilo que na impessoalidade alcança o não humano - um terceiro anônimo.

Ao rumarmos pelo caminho do não humano, do anonimato, presentes no texto clariceano, seguimos, agora, na direção daquilo que nomearemos, tomando de empréstimo um termo da escritora portuguesa Maria Gabriela Llansol, como "feminino de ninguém". Primeiramente, recortamos duas passagens de Clarice Lispector e Llansol, a fim de pensar aquilo que as aproxima e possibilita a leitura por esse caminho de ninguém. Na primeira cena, vinda de Água viva, descortina-se:
Quer ver comigo? Paisagem onde se passa essa música? ar, talos verdes, o mar estendido, silêncio de domingo de manhã Um homem fino de um pé só tem um grande olho transparente no meio da testa. Um ente feminino se aproxima engatinhando, diz com voz que parece vir de outro espaço, voz que soa não como a primeira voz mas em eco de uma voz primeira que não se ouviu. A voz é canhestra, eufórica e diz por força do hábito de vida anterior: quer tomar chá? [...] Alguém olha as unhas. Há um som que de longe faz: psiu! psiu!... Mas o homem-do-pé-só nunca poderia imaginar que o estão chamando. Inicia-se um som de lado, como a flauta que sempre parece tocar de lado - inicia-se um som de lado que atravessa as ondas musicais sem tremor, e se repete tanto que termina por cavar com sua gota ininterrupta a rocha. É um som elevadíssimo e sem frisos. Um lamento alegre e pausado e agudo como agudo não-estridente e doce de uma flauta. E a nota mais alta e feliz que uma vibração poderia dar. Nenhum homem da terra poderia ouvi-lo sem enlouquecer e começar a sorrir para sempre. Mas o homem de pé sobre o único pé - dorme reto. E o ser feminino estendido na praia não pensa. Um novo personagem atravessa a planície deserta e desaparece mancando. Ouve-se: psiu; psiu! E chama-se ninguém. ${ }^{49}$

Na segunda cena, (re)colhida do livro Lisboaleipzig 2-o ensaio de música, de Maria Gabriela Llansol, lemos: 
50. LLANSOL, Maria Gabriela. Lisboaleipzig 2 - o ensaio de música. Lisboa: Edições Rolim, 1994, p. 37.
Passeava-se distraidamente por Lisboa quando passou por ele uma mulher nova. Sentiu-lhe os seios baterem livres contra a camisa, as pernas e o garbo da garupa (não tinha palavra melhor) caminharem sem entraves como luzes fátuas vistas na luz translúcida de um balão veneziano. Aquele movimento era um misto de substância viva, aragem firme, e luz trémula. Passou por mim foi o que pensou mais tarde, e guardou como expressão exacta um porte altivo e um vestido ao vento.

Não é correcto dizer que Aossê nunca a viu. Vira-a, mas sem o rosto. Normalmente, é verdade que o verbo ver alguém supõe um rosto, conhecido ou a conhecer. Não vira ninguém é correcto, mas vira ninguém não é menos próprio: um rosto sem rosto. Fora-lhe mostrado - dir-se-ia - à medida das suas posses.

Se eu a tivesse visto teria de ir atrás dela porque o desejo nasceu-lhe

$\operatorname{logo}$

intenso. Uma vontade de ter de

De a ter, de me enfiar nela, sem magoar, e sem recusa. Um movimento que nem sequer esboçaria. Nunca o fizera: Estão-me a ver? - A ver o quê, Aossê? Sabemos que nunca irias atrás dela,

dizer-lhe ou dar-lhe a entender que me queria pôr nela Por isso o seu rosto não lhe foi mostrado.

Deram-lhe um feminino de ninguém a ver. Viva, veloz, livre, altiva. ${ }^{50}$
$\mathrm{Na}$ composição da primeira cena-paisagem, escrita por Clarice, além de ar, talos verdes, o ar, há a presença de "um homem fino de um pé só", de um "ente feminino", que não pensa, estendido na praia e, ainda, a travessia pela planície deserta de um novo personagem que desaparece mancando - um terceiro "anônimo, impessoal e neutro como o deserto” ${ }^{11}$ Parece ser nessa direção, ${ }^{52}$ de um terceiro anônimo, que Maria Gabriela Llansol também descreve a passagem desse vestido ao vento sem rosto - um "feminino de ninguém".

Desse tecido que veste um corpo de ninguém, como uma tessitura composta de fios anônimos, podemos citar o ensaio "Masculino, feminino, neutro", escrito por Roland Barthes. A partir da leitura do Sarrasine de Balzac, o autor escreve sobre a vestimenta, o neutro, um terceiro sexo:

É preciso, pois, voltar-se para a simbólica de Sarrasine. Seu centro aparente é o sexo. A vestimenta, material predileto dos romancistas, só conhece dois, o masculino e o feminino; Balzac tem, portanto, continuamente necessidade de um terceiro sexo, ou de uma ausência de sexo; não lhe resta então mais do que definir a castração, seja como uma mistura simultânea de masculino e de feminino (é o traje do velho), seja como uma sucessão dos dois (Zambinella se veste de mulher, depois de homem). Esta distribuição vestimentária traduz bem a dificuldade que o romancista sente em colocar simbolicamente
51. NUNES. Clarice Lispector ou o naufrágio da introspecção. In: Remate de Males, p. 67.

52. Cf. BRANCO. Três digressões sobre o texto ardente e o feminino de ninguém. (Texto inédito); BRANCO. Clarice, Duras (Texto inédito). 
53. BARTHES. Masculino, feminino, neutro. In: CARVALHAL; ZILBERMAN; BORDINI; NUNES; FILIPOUSKI (Org.). Masculino, feminino, neutro: ensaios de semiótica narrativa, p. 10-11. o castrado na estrutura institucional dos sexos, que é inelutavelmente binária; pois se nos atemos a essa estrutura, já que a ausência de marca faz nela o feminino, de que poderia se feito o neutro? Em realidade, e a linguística o atesta, o neutro não pode ser colocado diretamente numa estrutura sexual; nas línguas indo-européias, a oposição do masculino e do feminino é menos importante que a do animado e do inanimado; ela lhes é, portanto, subsequente. [...] o narrador não pode, pois, indexar o castrado senão discretamente, por aquilo que se poderia chamar o neutro feminino (uma criatura tão encantadora uma organização feminina). ${ }^{53}$

Em Sarrasine, como observa Barthes, a vestimenta só conhece duas dimensões: a masculina e a feminina, pois mesmo que Balzac tenha necessidade de um "terceiro sexo" - uma dimensão que rompa com a lógica binária - há quem diga que "o neutro não pode ser colocado diretamente em uma estrutura sexual”. No entanto, se há linhas de pensamento que qualificam o neutro com uma "ausência de sexo", propomos, a partir da passagem de Llansol, na qual há uma vestimenta para o ninguém, um vestido ao vento, pensarmos o terceiro, que adentra na paisagem deserta do texto clariceano, como um ausente, aquele que sem rosto, apaga-se, quem sabe, um "neutro feminino" - um "feminino de ninguém".

No texto "O feminino em biografemas: Llansol, Clarice, Duras”, Lucia Castello Branco faz uma leitura que avança na noção de feminino em direção ao que Llansol propõe como "feminino de ninguém". Como sugere a autora, a direção do "feminino de ninguém" parece se aproximar daquilo que Lacan anuncia em 1979, n’O seminário, livro 26: a topologia e o tempo, quando ele sugere a existência de "um terceiro sexo" - aquele que não pode subsistir em presença dos outros dois. ${ }^{54}$ Afinal, se há essa possibilidade de um "terceiro sexo", quem sabe, ele só possa existir, assim, sozinho, desconectado, longe dos limites que a linguagem impõe. Quem sabe, ele exista no movimento da escrita. Quem sabe ainda, ele exista na ramagem da árvore, nas asas de um pássaro solitário, na água que corre pelo chão seco - no não humano, naquilo que avança rumo ao ninguém.

Nesse sentido, se a escrita de Água viva é como uma "mensagem de pessoa só" ${ }^{55}$ e se, como a narradora escreve, "ninguém é eu. Ninguém é você. Esta é a solidão", ${ }^{56}$ da pessoa, resta aquele que, em sua solidão, abandonou sua pessoalidade (sua persona?) $)^{57}$ - um ninguém. Em Água viva, o "emissor é, pois, personne (ninguém), ou seja, alguém que seja um ser inumano. [...] É por isso que o destinatário, conforme a voz narrativa, não lerá jamais o que ela escreve, uma vez que o tema é atemático e se situa no limite da legibilidade" ${ }^{58}$

Portanto, como observa Lucia Castello Branco, "é também em direção a um 'feminino de ninguém' que veremos a questão do feminino avançar, na obra de Clarice Lispector,
54. Cf. LACAN. El seminario, libro 26: la topologia y el tempo. (Seminário inédito).

55. LISPECTOR. Água viva, p. 43. 56. LISPECTOR. Água viva, p. 35

57. LISPECTOR. $A$ descoberta do mundo, p. 81.

58. PETERSON. Clarice Lispector: uma leitura do sujeito. In: Organon, p. 111.

\begin{tabular}{|c|c|c|c|c|}
\hline EM TESE & BELO HORIZONTE & v. 21 & SET.-DEZ. 2015 & SOUZA. 0 relevo de Água viva: Clarice Lispector e a escrita da paisagem \\
\hline
\end{tabular}



Dugrafemas. Llansol, Clarice, dito).

60. BLANCHOT. O espaço literário, $\mathrm{p}$

61. BLANCHOT. O espaço literário, p. 62. BRANCO. O sopro Clarice. In:
; BRANDÃO. A mulher escrita, p. 205. a partir da redução da vida a alguns 'pormenores sutis', a alguns biografemas". ${ }^{59}$ Pois se o texto clariceano segue entre cortes e perdas, em um movimento de apagamento dos excessos autobiográficos, é possível pensarmos naquilo que indica Blanchot: a passagem do "Eu" ao "Ele" que, por sua vez, converte-se em um ninguém.

O "Ele" que toma o lugar do "Eu", eis a solidão que sobrevém ao escritor por intermédio da obra. "Ele" não glorifica a consciência em um outro que não eu, [...] "Ele" sou eu convertido em ninguém, outrem se torna o outro, é que, do lugar onde estou, não possa mais dirigir-se a mim que aquele que se me dirige não diga "Eu", não seja ele mesmo. ${ }^{0}$

Ao descolar-se dele mesmo, o escritor, imerso na solidão que habita a obra, atravessado pelo interminável da escrita é, então, convertido em ninguém. Nesse movimento, “o 'Eu' que somos reconhece-se ao soçobrar na neutralidade de um 'Ele' sem rosto". ${ }^{61}$

Acreditamos que seja também na conversão de um "Eu" em um "Ele sem rosto" (ou em um "Ela sem rosto") que a escrita de Clarice opera. Como propõe Lucia Castello Branco, no livro Um sopro de vida, "por meio de um suposto desdobramento daquele que é nomeado o 'Autor' em sua 'personagem' 'Ângela', opera-se essa passagem do 'Eu' a seu 'Ele”. ${ }^{62}$ Desse desdobramento, lemos: "Quem fala parece que sou eu, mas não sou, É uma 'ela' que fala em mim." ${ }^{3}$ Parece-nos, que, em Água viva, há também essa conversão: um "Eu” fala a um "tu" que nada responde. Tem-se, desse modo, a dobra do "Eu" que, sem o ela, o ele, lança-se ao tu, ao ti, ao it, ao ninguém.

Quem sabe o tu esteja próximo ao it, pois o "tu é duro como pedra e recusa-se a ser atingido, mas a água é mole... Água é it? Dentro da ostra, sim. Recoberta pela dureza da concha”. ${ }^{64}$ Quem sabe, ainda, se na combinação de letras que compõem essa escrita, o eu e o tu sejam permutáveis e, por isso, "podem integrar-se com o não-humano - as palavras, os animais, a natureza, a 'coisa', ou até mesmo o 'it”. ${ }^{65}$

Assim, sem o ele/o ela, com a paisagem que se abre em Água viva, há o abandono do humano e aparecimento de formas vegetais e animais que se ramificam ao longo da escrita. Como observa Roberto Correia dos Santos:

Abandonam-se sequencialidades demarcadas por conectivos e produzidas por efeito de régua, compasso, esquadro. Abandona-se esse cálculo geométrico, para construir-se por formas livres, vegetais, sinuosas, suculentas; a frase em desenvolvimento, como que seguindo a direção da luz natural, em acordo com a umidade do solo, as características do terreno. [...] A escrita, sob a forma das folhas e das ramagens. A escritura como natureza, na maioria das vezes vegetal, mas, muitas
63. LISPECTOR. Um sopro de vida, p. 73.

64. MASTROBERTI. A palavra em quarta dimensão: leituras de Agua viva, de Clarice Lispector. In: Letrônica, p. 322.

65. MATOS. Romance sem romance: o caso de Água viva de Clarice Lispector. In: Letrônica, p. 310 
outras, animal. [...] E para além desse amor pelas linguagens que se ramificam e proliferam como a dos troncos, galhos, raízes e para além ainda do amor pela linguagem dos animais - que vivem simplesmente - o grande amor pelo que está fora tanto da natureza quanto da cultura, e até mesmo fora da linguagem $-o$ grande amor pelo que chamará de it: o nem ele, nem ela - o neutro, o impessoal, o âmago. ${ }^{66}$

Desse modo, em Água viva, abandonam-se as sequencialidades, que poderiam narrar uma história; abandona-se o gênero humano, que poderia encadear os acontecimentos no texto; abandonam-se os traços, que haveriam de cobrir as letras com fios de pessoalidade. Com esse movimento de renúncia, não há uma narrativa a ser contada, mas, sim, fragmentos de letras que escorrem pela superfície do livro; não há uma dimensão do pessoal, mas um caminho rumo ao it, ao impessoal, a um ninguém; não há, ainda, um ele/um ela mas há um não humano que se lança em meio às plantas, às raízes, aos galhos, às folhagens, aos animais.

$\mathrm{Na}$ "direção da luz natural" e entre os milhares de reflexos do sol que atravessam as páginas de Água viva, há um caminho que se abre em pura paisagem. Lá, em meio a uma ramificação que se amplifica pela "densa selva de palavras", no ritmo de uma música selvática, há folhas esmagadas e plantas aveludadas e carnívoras. Nesse cenário, ao mencionar os sacrifícios animais e cerimônias de sortilégio, feras e cavalos em carros alegóricos, ela escreve sobre a preferência por certo tipo de paisagem: "Gosto é das paisagens de terra esturricada e seca, com árvores contorcidas e montanhas feitas de rocha e com uma luz alvar e suspensa. [...] Sou uma árvore que arde com duro prazer" ${ }^{67}$

Ela, cujo "impulso se liga ao das raízes das árvores", ${ }^{6}$ segue por um caminho de raízes que rebentam a terra. A escrita que se alastra pelo aberto dessa paisagem, liga-se à força da natureza e das árvores. O texto se funde com esse espaço, é assim que ela escreve: "Como se arrancasse das profundezas da terra as nodosas raízes de árvore descomunal, é assim que te escrevo, e essas raízes como se fossem poderosos tentáculos como volumosos corpos nus de fortes mulheres" ${ }^{69}$

Terra, raízes, corpos, mulheres. No aberto desse lugar, ela, sozinha, ao buscar viver o que é redondo e amplo, conta: "cerco-me por plantas carnívoras e animais legendários, tudo banhado pela tosca e esquerda luz de um sexo mítico. Vou adiante de modo intuitivo e sem procurar uma ideia: sou orgânica" ${ }^{70}$ Há uma força que a guia, vinda de uma "sensualidade vital de estruturas nítidas e das curvas que são organicamente ligadas a outras formas curvas". ${ }^{71}$ Da natureza em cântico coral, das curvas orgânicas, das quais escorre resina pelo tronco das árvores, ressoam ruídos de plantas. Sobre isso, ela escreve:
67. LISPECTOR Água viva, p. 39.

68. LISPECTOR Água viva, p. 42

69. LISPECTOR. Água viva, p. 20

70. LISPECTOR. Água viva, p. 23-24.

71. LISPECTOR. Água viva, p. 40. 
Na minha viagem aos mistérios ouço a planta carnívora que lamenta tempos imemoriais [...] As inscrições cuneiformes quase ininteligíveis falam de como conceber e dão fórmulas sobre como se alimentar da força das trevas. Falam das fêmeas nuas e rastejantes. E o eclipse do sol causa terror secreto que no entanto anuncia um esplendor de coração. ${ }^{72}$

Observamos, então, que, no aberto da paisagem de Água viva misturados entre os ramos de letras, há "Fêmeas nuas e rastejantes, inscrições cuineiformes, plantas e animais legendários banhados pela luz de um sexo mítico". Das folhagens da escrita desse livro, há, pois, uma "natureza que é sexualmente viva":

A densa selva de palavras envolve espessamente o que sinto e vivo, e transforma tudo o que sou em alguma coisa minha que fica fora de mim. A natureza é envolvente: ela me enovela toda e é sexualmente viva, apenas isto: viva. ${ }^{73}$

Da natureza que é sexualmente viva, há, ainda, o espalhamento do "erotismo próprio do que é vivo" pelos corpos e lugares:

O erotismo próprio do que é vivo está espalhado no ar, no mar, nas plantas, em nós, espalhado na veemência de minha voz, eu te escrevo com minha voz. E há um vigor de tronco robusto, de raízes entranhadas na terra viva que reage dando-lhes grandes alimentos.
Podemos articular essas passagens do vivo de Agua viva com aquilo que desenvolve Maria Gabriela Llansol, em sua obra, como a paisagem - "o terceiro sexo". Em Onde vais, Dramapoesia?, Llansol oferta "a boa nova anunciada à natureza".

tudo participa das diversas partes: a boca, a copa frondosa, o cogumelo, a falésia, o mar, a erva rasteira, a leve aragem, os corpos dos amantes. Os três sexos que movimentam a dança do vivo: o homem, a mulher, a paisagem.

Esta é a novidade: a paisagem é o terceiro sexo.

A paisagem não tem um sexo simples. Nem o homem, nem a mulher. Há, no entanto, alguns fatos que aqui consigno:

$\mathrm{Na}$ paisagem ou na geografia imaterial da espécie terrestre, os seres humanos distribuem-se em vagabundos, em formadores e poetas.

Os vagabundos erram à procura de uma nova paisagem. São desde sempre, exteriores à comunidade. Os construtores são os elementos estabilizadores que prendem toda a geografia imaterial á vida cotidiana. Os formadores sentem essa geografia porque o seu órgão é o coração. Os poetas vêem, e anunciam a geografia imaterial por vir.

Os construtores, os formadores são peregrinos.

Os poetas também o são, de certo modo. Há uma grande afinidade que os liga aos vagabundos. Porque são os únicos que desejam o retorno do ser como Belo.

E vital conhecer a paisagem..$^{75}$
75. LLANSOL. Onde vais, DramaPoesia?, p. 44-45. 
76. BRANCO. O feminino em biografemas: Llansol, Clarice, Duras. (Texto inédito).
Nem ele, nem ela, nem o homem, nem a mulher, mas o erotismo próprio do que é vivo, a paisagem, um terceiro sexo. Nesse sentido, a escrita de Clarice Lispector, ao estabelecer uma passagem do pessoal ao impessoal, parece enveredar pelas vias do não humano, do vivo. Vemos, então, o texto clariceano avançar fora dos limites do binarismo e na direção de um impessoal. Esse movimento instaura uma outra lógica, na qual há uma tentativa de conceber um feminino não referido ao masculino - um "feminino de ninguém" ${ }^{76}$ Portanto, o que vemos/lemos no relevo de Água viva são os rastros deixados por esse "ente feminino", que sabe ser vital conhecer a paisagem e, por isso, avança sozinho na imensidão dela.

\section{REFERÊNCIAS}

BARTHES, Roland. Masculino, feminino, neutro. In: CARVALHAL, Tania Franco; ZILBERMAN, Regina Levin; BORDINI, Maria da Glória; NUNES, Luiz Arthur; FILIPOUSKI, Ana Mariza (Org.). Masculino, feminino, neutro: ensaios de semiótica narrativa. Porto Alegre: Globo, 1976. p. 1-17.

BLANCHOT, Maurice O livro por vir São Paulo: Martins Fontes, 2005. BLANCHOT, Maurice. O espaço literário. Rio de Janeiro: Rocco, 2011

BRANCO, Lucia Castello. O sopro Clarice. In: ; BRANDÃO Ruth Silviano. A mulher escrita. Rio de Janeiro: Lamparina, 2004. p. 201-215.
BRANCO, Lucia Castello. Três digressões sobre o texto ardente e o feminino de ninguém. (Texto inédito).

BRANCO, Lucia Castello. O feminino em biografemas: Llansol Clarice, Duras. (Texto inédito).

FREUD, Sigmund. A questão da análise leiga: conversações com uma pessoa imparcial. In Um estudo autobiográfico;

inibições sintomas e ansiedade; a questão da análise leiga; outros trabalhos. (1925-1926). Obras psicológicas completas de Sigmund Freud. Rio de Janeiro: Imago, 1996. (Edição Standard Brasileira das obras psicológicas completas de Sigmund Freud, 20). p. $175-240$

FREUD, Sigmund. Feminilidade. In

Novas conferências introdutórias sobre psicanálise e outros trabalhos. (19321936). Obras psicológicas completas de Sigmund Freud. Rio de Janeiro: Imago, 1996. (Edição Standard Brasileira das obras psicológicas completas de Sigmund Freud, 22). p. 113-134.

LACAN, Jacques. O seminário, livro 20: mais, ainda (1972-1973). Rio de Janeiro: Jorge Zahar, 1985.

LACAN, Jacques. O aturdito. In Outros escritos. Rio de Janeiro: Jorge Zahar, 2003. p. 448-497.

LACAN, Jacques. El seminario, libro 26: la topologia y el tiempo. 1979. (Seminário inédito).

LISPECTOR, Clarice. A paixão segundo G.H. Rio de Janeiro: Rocco, 2009.

LISPECTOR, Clarice. Água viva. Rio de Janeiro: Rocco, 1998. 
LISPECTOR, Clarice. Um sopro de vida. Rio de Janeiro: Rocco, 1999.

LISPECTOR, Clarice. A descoberta do mundo. Rio de Janeiro: Rocco, 1999.

LLANSOL, Maria Gabriela. Lisboaleipzig 2: o ensaio de música. Lisboa: Edições Rolim, 1994.

\section{LLANSOL, Maria Gabriela. Onde vais, Drama-Poesia? Lisboa:} Relógio D'Água, 2000.

MASTROBERTI, Paula. A palavra em quarta dimensão: leituras de Água viva, de Clarice Lispector. Letrônica, Porto Alegre, v. 2, n. 1 p. 317-329, 2009

MATOS, Anderson Hakenhoar. Romance sem romance: o caso de Água viva de Clarice Lispector. Letrônica, Porto Alegre v. 2, n. 1. p. 306-316, 2009

NASCIMENTO, Evando. Clarice Lispector: uma literatura pensante. Rio de Janeiro: Civilização Brasileira, 2012

NUNES, Benedito. Clarice Lispector ou o naufrágio da introspecção. In: Remate de Males: Revista do Departamento

de Teoria Literária e do Instituto de Estudos da Linguagem. Campinas, UNICAMP, n. 9, p. 63-70, maio 1989.

PETERSON, Michel. Clarice Lispector: uma leitura do sujeito. Organon: Revista do Instituto de Letras, Rio Grande do Sul, UFRGS, v. 17, n. 17, p. 105-112, 1991
POMMIER, Gérard. O Aberto, até onde as palavras podem nos transportar. In A exceção feminina: os impasses do gozo. Rio de Janeiro: Jorge Zahar, 1991. p. 94-104.

SANT 'ANNA, Affonso Romano de. O ritual epifânico do texto. In: NUNES, Benedito (Coord.). A paixão segundo G.H. Edição crítica. Madrid, Paris, México, Buenos Aires, São Paulo, Lima, Guatemala, São José da Costa Rica, Santiago de Chile: ALLCA XX/Scipione cultural, 1997. p. 241-261

SANTOS, Roberto Corrêa. Na cavidade do rochedo: a pósfilosofia de Clarice Lispector [livro eletrônico]. São Paulo:

IMS - Instituto Moreira Salles, 2012. Disponível em: < http:// claricelispectorims.com.br/files/uploads/books/book_4.pdf> Acesso em: 22 jan. 2014.

SEVERINO, Alexandrino. As duas versões de Água viva. Remate de Males: Revista do Departamento de Teoria Literária e do

Instituto de Estudos da Linguagem, Campinas, UNICAMP, n. 9, p. 115-118, maio 1989 